\title{
Business Cycle Synchronization and Regional Integration: \\ A Case Study for Central America
}

\author{
Norbert Fiess \\ World Bank \\ nfiess@worldbank.org
}

\begin{abstract}
In early January 2003, the United States and Costa Rica, El Salvador, Guatemala, Honduras and Nicaragua launched official negotiations for the Central American Free Trade Agreement (CAFTA), a treaty that would expand NAFTA-style trade barrier reductions to Central America. With deeper trade integration between Central America and the United States, it is expected that there will be closer links in business cycles among Central America and the United States. The aim of this paper is to assess the degree of business cycle synchronization between Central America and the United States. We find a relatively low degree of business cycle synchronization within Central America as well as between Central America and the United States. We further expect that based on the current trade structure between Central America and the United States, business cycle synchronization with the United States is expected to increase only modestly with further trade expansion, making the coordination of macro policies within CAFTA somewhat less of a priority.
\end{abstract}

JEL: F15, F42

Keywords: Regional integration, business cycle synchronization, trade structure, CAFTA

World Bank Policy Research Working Paper 3584, April 2005

The Policy Research Working Paper Series disseminates the findings of work in progress to encourage the exchange of ideas about development issues. An objective of the series is to get the findings out quickly, even if the presentations are less than fully polished. The papers carry the names of the authors and should be cited accordingly. The findings, interpretations, and conclusions expressed in this paper are entirely those of the authors. They do not necessarily represent the view of the World Bank, its Executive Directors, or the countries they represent. Policy Research Working Papers are available online at http://econ.worldbank.org. 


\section{Introduction}

In early January 2003, the United States and Costa Rica, El Salvador, Guatemala, Honduras and Nicaragua launched official negotiations for the Central American Free Trade Agreement (CAFTA), a treaty that would expand NAFTA-style trade barrier reductions to Central America. CAFTA is part of a bigger project to promote regional integration throughout the Americas, with the ultimate aim of establishing a Free Trade Area of the Americas (FTAA).

With deeper trade integration between Central America and the United States, it is expected that there will be closer links in business cycles among Central America and the United States. From a theoretical point of view, the impact of trade integration on business cycle synchronization is not clear, as increased trade can lead business cycles to convergence or divergence: if trade integration leads to increased inter-industry trade as a part of a specialization process, then business cycles are likely to become less similar as shocks specific to particular industries will become responsible for shaping business cycles. On the other hand, if trade integration leads to a higher share of intra-industry trade, business cycles will become more similar, as industryspecific shocks affect trading partners in a similar way.

Assessing business cycle synchronization between Central America and the United States is not only important for a better understanding of the influence of important trading partners on the business cycle fluctuations in the domestic economies. Information about the degree of business cycle synchronization is important as it provides information on the necessity of independent fiscal and monetary policy. If the business cycles are similar and shocks are common, then a coordination of macro policies can become desirable, with a common currency as the ultimate form of policy coordination. On the other hand, if shocks are predominately country-specific resulting in a low degree of business cycle synchronization - then, the ability to conduct independent monetary and fiscal policy is generally seen as important in helping an economy adjust to a new equilibrium.

This paper has three objectives. First, using state-of the art econometric techniques, we attempt to measure the degree of business cycle synchronization within Central America as well as with the United States, its main trading partner. Second, we calculate measures of inter and intra- 
regional trade for Central America and quantify the relationship between trade intensity, trade structure and business cycle synchronization and discuss how trade integration within CAFTA is likely to shape future business cycle patterns in the region. Third, we provide some policy advice on the appropriateness of macro coordination for Central America conditional on its trade structure. As El Salvador unilaterally dollarized in 2000, it seems highly relevant to inform the debate on this front.

Data availability for Central America seriously limits the scope for any econometrical analysis. To provide some inference about the level of business cycle synchronization and the link between trade structure and business cycle synchronization in Central America we make use of annual data on GDP from 1965 to 2002 and monthly data on economic activity from 1995 to 2003.

This paper is organized as follows. Section 2 provides measures of business cycle synchronization for Central America based on different econometrical filters and based on annual and monthly data. Section 3 analyzes the link between Central America's trade structure and business cycle synchronization with the United States. Section 4 concludes.

\section{The degree of Business Cycle Synchronization in Central America}

\subsection{Data and methodology}

The degree of business cycle synchronization is important as it provides information on the necessity of independent fiscal and monetary policy. If the business cycles are similar and shocks are common, then a coordination of macro policies can become desirable, with a common currency as the ultimate form of policy coordination. On the other hand, if shocks are predominately country-specific, then the ability to conduct independent monetary and fiscal policy is usually seen as important in helping an economy adjust to a new equilibrium.

As shocks are not observed directly, empirical studies rely on econometric methods for their identification. Helg et al. (1995) and Bayoumi and Eichengreen (1993) adopt a structural VAR approach, whereas Artis and Zhang (1995) develop an identification scheme based on cyclical 
components. Rubin and Tygesen (1996), Beine and Hecq (1997) and Beine, Candelon and Hecq (2000) use a codependence framework. Filardo and Gordon (1994), Beine, Candelon and Sekkat (1999) and Krolzig (2001) use a Markov Switching VAR model. This empirical work demonstrates that it is important to distinguish between short and long-run effects. Bayoumi and Eichengreen (1993), Helg et al. (1995) and Rubin and Thygesen (1996) use differenced variables in the VAR representation. However, such a specification does not allow for long-run relationship between the variables. Beine and al. (2000) overcome this by investigating simultaneously common trends and common cycles, where evidence of a common European cycle is taken as evidence of perfect synchronization of shocks. Breitung and Candelon (2001) use a frequency domain common cycle test to analyze synchronization at different business cycle frequencies.

We use annual data from 1965 to 2002 for real GDP and trade figures, and monthly data on industrial production and economic activity from 1995 to 2002. GDP data is from IFS, data on industrial production are from Central Bank statistics. Trade data is from WITS and Direction of Trade Statistics.

The key variable in our study is the degree of business cycle synchronization between countries $i$ and $j$. To measure this variable, we follow Frankel and Rose (1998) and compute the correlation between the cyclical component of the output in countries $i$ and $j$, where a higher correlation implies a higher degree of business cycle synchronization. The cyclical component of output is obtained using different de-trending methods. Given the lack of consensus on the optimal procedure and the sensitivity of the cycle to the de-trending method, this approach should provide a robustness check of our results. For annual data we use first-differencing and bandpass filtering (Baxter and King, 1999). Spectral analysis is used to assess business cycle synchronization with monthly data.

\subsubsection{Annual Data: 1965 -2002}

Band pass filtered data, our preferred method for business cycle extraction in this section, shows that in Central America business cycle synchronization is highest between Costa Rica, Guatemala, El Salvador and Honduras. Nicaragua and Panama appear to be follow a different 
cycle, as correlation across business cycles is in most cases even negative, though not statistically significant. ${ }^{1}$

Interestingly, correlation with the United States business cycle is also high. In the case of Costa Rica, El Salvador and Honduras business cycle synchronization with the United States appears even higher than among regional neighbors, indicating that bilateral relationships with the United States through trade and remittances are more important than regional effects. Somewhat surprisingly, business cycle synchronization between United States and Panama, which adopted full dollarization in 1904, appears to be much lower than in the rest of Central America, with the exception of Nicaragua. ${ }^{2}$ It appears that based on business cycle synchronization, the rest of Central America would be better candidates for a currency union with the United States than Panama. In fact, business cycle synchronization between the United States and Costa Rica, Guatemala, Honduras and El Salvador is higher even that the EU average (0.43).

Business cycle synchronization in the two Mercosur countries, Argentina and Brazil, is below the levels of Costa Rica, El Salvador and Guatemala. While business cycle synchronization is also substantial between the United States and Canada, it is however surprisingly low between the United States and Mexico. The low finding of business cycle synchronization between the United States and Mexico, as well as Brazil and Argentina is partly explained by long time period (1965-2002) under consideration, the next section shows that there has been a substantial increase in business cycle synchronization in the more recent past.

Table 3 shows business cycle synchronization between Central American countries after controlling for common impact of the United States business cycle. ${ }^{3}$ Once the common impact of the United States business cycle is removed, it appears that only Costa Rica and Guatemala, Costa Rica and El Salvador and Guatemala and Honduras are affected by common factors other than the United States business cycle. As these countries also account for the largest share of

\footnotetext{
${ }^{1}$ Results based on first-differences are reported in the appendix.

${ }^{2}$ Panizza et al. (2000) report a similar result.

3 Table 3 reports the correlation between the cyclical components of band pass filtered GDP series orthogonal to the US business cycle.
} 
intra-regional trade, this finding can be taken in support of the often postulated positive relationship between trade intensity and business cycle symmetry.

Table 1. Buisness Cycle Synchronization - Band pass filter - Central America

\begin{tabular}{|c|c|c|c|c|c|c|}
\hline \multirow[t]{2}{*}{ bandpass } & \multicolumn{6}{|c|}{ Central America } \\
\hline & Costa Rica & El Salvador & Guatemala & Honduras & Nicaragua & Panama \\
\hline Costa Rica & 1.000 & & & & & \\
\hline El Salvardor & 0.604 & 1.000 & & & & \\
\hline Guatemala & 0.632 & 0.238 & 1.000 & & & \\
\hline Honduras & 0.524 & 0.442 & 0.590 & 1.000 & & \\
\hline Nicaragua & -0.214 & 0.015 & -0.142 & -0.157 & 1.000 & \\
\hline Panama & -0.007 & -0.062 & -0.087 & -0.011 & 0.088 & 1.000 \\
\hline Argentina & 0.354 & 0.111 & 0.187 & 0.043 & -0.086 & 0.148 \\
\hline Brazil & 0.350 & 0.028 & 0.407 & 0.174 & -0.162 & -0.001 \\
\hline Mexico & 0.151 & -0.335 & 0.395 & 0.168 & -0.255 & 0.323 \\
\hline Canada & 0.621 & 0.276 & 0.492 & 0.359 & -0.214 & -0.336 \\
\hline USA & 0.687 & 0.506 & 0.463 & 0.679 & -0.163 & -0.148 \\
\hline France & 0.239 & 0.113 & 0.394 & 0.152 & -0.170 & -0.138 \\
\hline Germany & 0.167 & 0.107 & 0.308 & 0.107 & -0.138 & 0.280 \\
\hline Portugal & 0.124 & -0.088 & 0.540 & 0.423 & -0.127 & -0.085 \\
\hline Spain & 0.175 & 0.136 & 0.389 & 0.057 & 0.167 & -0.218 \\
\hline UK & 0.402 & 0.479 & 0.241 & 0.459 & -0.268 & -0.323 \\
\hline
\end{tabular}

Table 2. Business Cycle Synchronization - Other FTAs

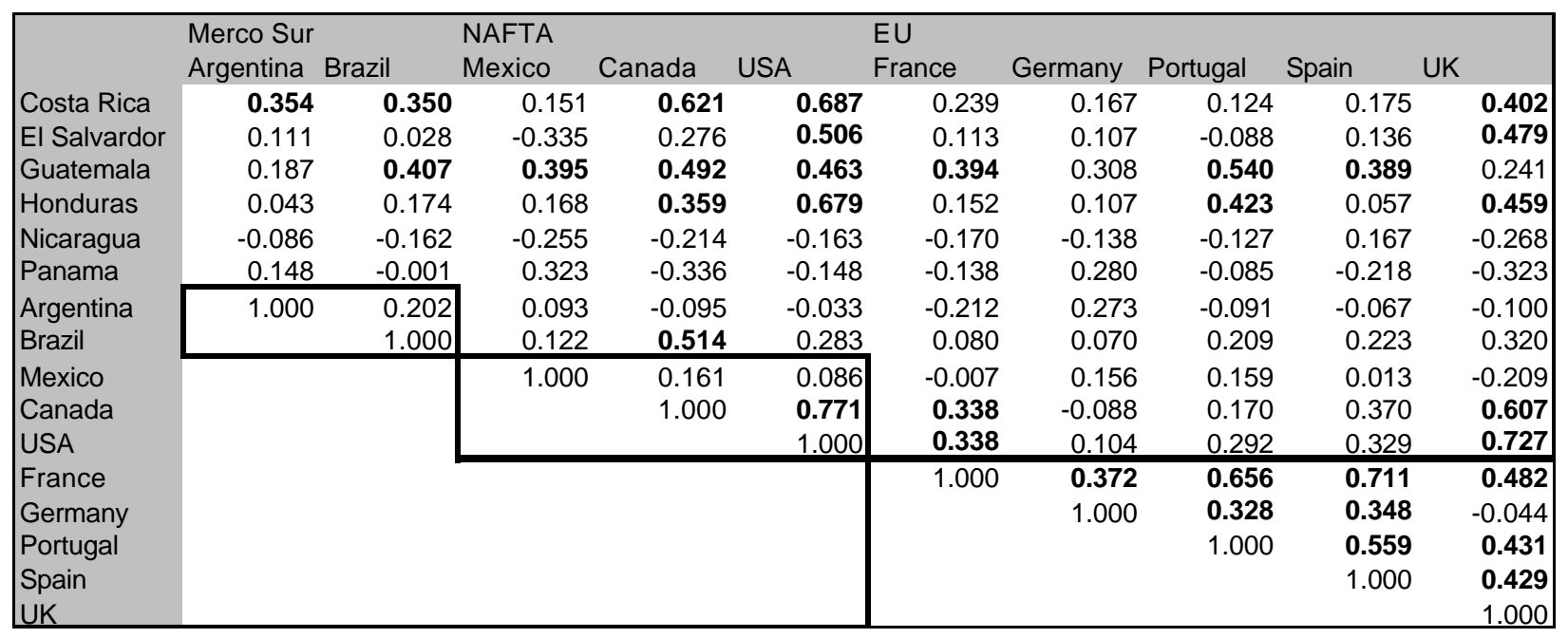


Table 3. Business Cycle Synchronization - orthogonal to US business cycle

\begin{tabular}{|lrrrrr|}
\hline & Costa Rica & El Salvador & Guatemala Honduras & Nicaragua \\
Costa Rica & 1.000 & & & & \\
El Salvador & $\mathbf{0 . 4 0 9}$ & 1.000 & & & \\
Guatemala & $\mathbf{0 . 4 8 8}$ & 0.006 & 1.000 & & \\
Honduras & 0.104 & 0.157 & $\mathbf{0 . 4 2 1}$ & 1.000 & \\
Nicaragua & -0.141 & 0.115 & -0.076 & -0.063 & 1.000 \\
Panama & 0.134 & 0.014 & -0.021 & 0.118 & 0.065 \\
\hline
\end{tabular}

\subsubsection{Monthly Data: 1995 - 2003}

The business cycle is usually defined in the range of 6 to 32 quarters, as such, the low frequency of annual data might be insufficient to fully assess the degree of business cycle synchronization In this section we therefore complement our analysis in the previous section with an analysis of monthly data, where output is proxied by seasonally adjusted monthly indices of industrial production and economic activity.

We use spectral analysis to estimate the correlation at different frequencies and use the average coherence at business cycle frequency (6 to 32 quarters) of year-over-year changes in economic activity as a summary measure of business cycle synchronization (Garnier, 2003). The advantage of using cross-spectral densities over simple correlations in the analysis of business cycle synchronization is twofold. First, spectral analysis avoids possible business cycle distortions due to filtering, it is well known that the cycles change with the de-trending method (Canova, 1998). Second, contemporaneous correlation is unable to take lagged co-movement into account. As coherence measures the correlation between two series in the frequency domain and further provides information on the phase lead/lag it captures provides a richer analysis of the business cycle dynamics. While the coherence measures to what extend two business cycles are dominated by the same frequency, the phase lag shows to what extend elements with the same frequency lag each other. In sum, a high degree of business cycle synchronization implies a high coherence and a low phase lag.

Table 4 shows the average coherence at business cycle frequency between year-over-year growth rates of economic activity during 1995 and 2003. Encouragingly, the results broadly confirm the findings of the previous section. 
Table 4. Average Coherence at Business Cycle Frequency

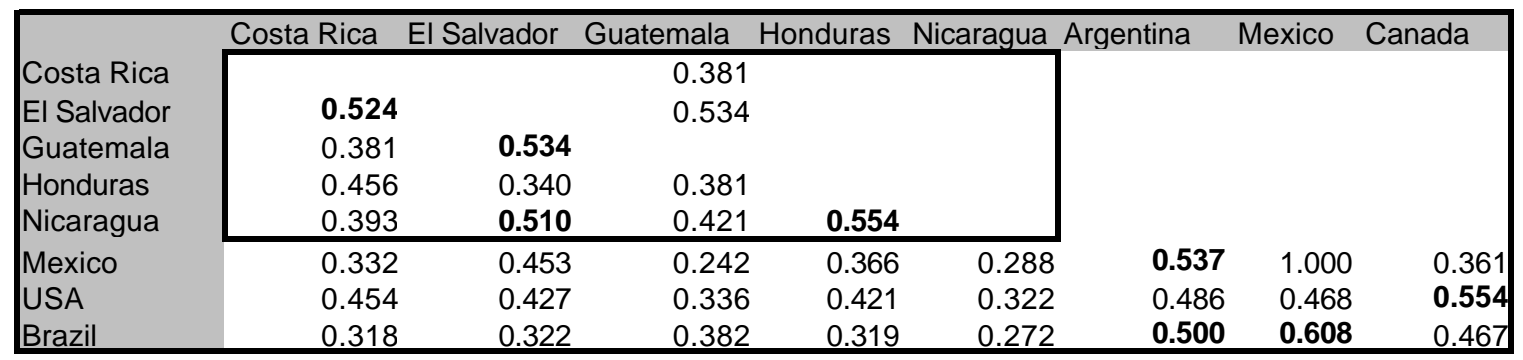

Within Central America, business cycle synchronization is found to be again highest between Costa Rica and El Salvador, El Salvador and Guatemala, El Salvador and Nicaragua, and Honduras and Nicaragua. With respect to the United States, business cycle synchronization is highest for Costa Rica, El Salvador and Honduras, however, at levels lower that those prevailing in member countries in NAFTA and MERCOSUR. ${ }^{4}$

\section{Trade Structure and Business Cycle Synchronization}

\subsection{Trade Structure, Exchange Rate Stability and Business Cycle Synchronization}

The impact of trade liberalization on business cycle synchronization is theoretically ambiguous. Standard trade theory (Heckscher-Ohlin) predicts that the removal of trade barriers leads to an increasing specialization in production, leading to inter-industry trade patterns. As industryspecific specialization increases, industry-specific shocks, e.g. a shock to commodity prices, will make business cycles more dissimilar and hence decrease the degree of business cycle synchronization.

Experience from industrial countries shows however a trend toward intra rather than interindustry trade. If intra-industry trade is vertical, i.e. particular countries are specializing on different production stages of the same good, then, industry-specific shocks will make business cycles more similar. The same results if intra-industry trade is horizontal, i.e. countries trade and compete with the same products. In that case industry-specific shocks are also expected to increase business cycle synchronization.

\footnotetext{
${ }^{4}$ We abstain from reporting the phase lag as the phase lag is very poorly estimated if the coherence is small, which is the case for most country pairings in Table 4.
} 
Exchange rate stability is often considered important for trade integration. While volatile exchange rates increase transaction costs, misaligned exchange rates create unfair competitive advantages for the trading partner with the undervalued currency and generate political backlash against free trade in the countries confronted with an import surge. Exchange rate stabilization and monetary coordination are therefore often seen as an effective tool to contain the political pressure against further trade integration. However, as Eichengreen and Taylor (2003) point out, the vertical-versus-horizontal structure of trade is also decisive in shaping the competitive impact of bilateral exchange rate fluctuations. If trade and production are predominately vertical, i.e. producers specializes in different stages of the production process - as in the case of NAFTA, where Mexican producers provide inputs and assembly operations for manufacturers designed and marketed in the United States - the exchange rate fluctuations are less likely to increase competition. The case is reversed if intra-industry trade is predominately horizontal. In this case, the impact of undervalued exchange rates is likely to be much larger. This effect is amplified further, if the goods in question cannot be relocated to a third market (regional goods, i.e. they are uncompetitive outside the regional trade area. (Fernandez-Arias, Panizza and Stein, 2002)).

To summarize, intra-industry trade, vertical or horizontal, is expected to increase business cycles synchronization; exchange rate instability can become a concern for further trade integration if intra-industry trade is horizontal rather than vertical.

\subsection{Central America's Trade Structure}

Tables 5 and 6 provide information about Central America's trade structure. Trade patterns of NAFTA, and some countries in EU and MERCOSUR are again provided for comparison. Unlike for NAFTA, EU and MERCOSUR members, trade, measured as bilateral exports over total exports, in Central America is not predominantly intra-regional. Even within the so-called Northern Triangle (Guatemala, El Salvador and Honduras), and between El Salvador and Nicaragua, bilateral exports as a ratio of total exports barely exceeds 10 percent. The United States is by far Central America's most important trading partner; although trade with the EU is also some of significance. As there appears to be some underreporting of exports to the United States, imports from Central America to the United States as reported by the United States are 
provided as an alternative measure. Based on this measure, exports to the United States account for more than 60 percent in the case of Costa Rica, El Salvador and Guatemala.

Table 5. Central America's Trade Structure: Bilateral Exports/Total Exports

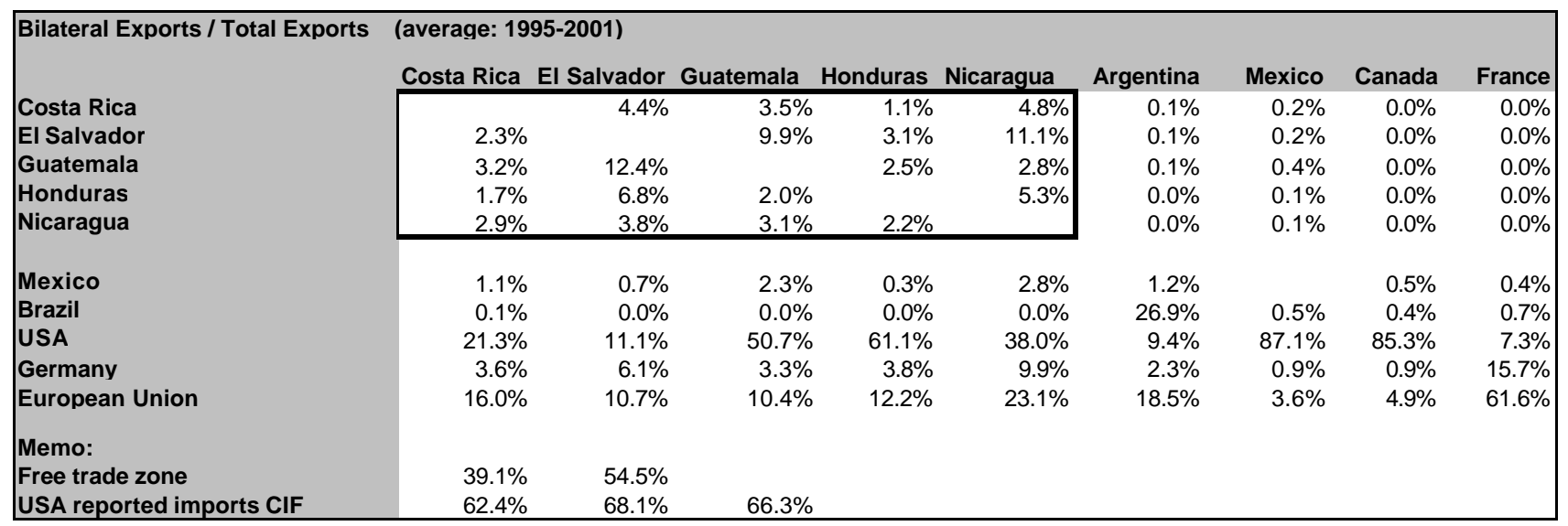

Note: Interpretation of this table is as follows. The table should be read column-wise, where each row represents the share in total column -countries exports. As an example, the top-left figure indicates that exports from Costa Rica to El Salvador represent $2.3 \%$ of Costa Rica's total exports.

Source: Direction of Trade Statistics

Table 6. Central America's Trade Structure: Bilateral Exports/GDP

\begin{tabular}{|c|c|c|c|c|c|c|c|c|c|}
\hline \multicolumn{10}{|c|}{ Bilateral Exports / GDP (average: 1995 - 2001) } \\
\hline & Costa Rica & EI Salvador & Guatemala & Honduras & Nicaragua & Argentina & Mexico & Canada & France \\
\hline \multirow{3}{*}{$\begin{array}{l}\text { Costa Rica } \\
\text { El Salvador } \\
\text { Guatemala }\end{array}$} & \multirow[b]{2}{*}{$0.8 \%$} & $0.8 \%$ & $0.7 \%$ & $0.6 \%$ & $1.2 \%$ & $0.01 \%$ & $0.05 \%$ & $0.01 \%$ & $0.01 \%$ \\
\hline & & & $1.8 \%$ & $1.5 \%$ & $2.9 \%$ & $0.01 \%$ & $0.05 \%$ & $0.00 \%$ & $0.01 \%$ \\
\hline & $1.1 \%$ & $2.3 \%$ & & $1.2 \%$ & $0.7 \%$ & $0.01 \%$ & $0.11 \%$ & $0.01 \%$ & $0.00 \%$ \\
\hline Honduras & $0.6 \%$ & $1.3 \%$ & $0.4 \%$ & & $1.4 \%$ & $0.00 \%$ & $0.03 \%$ & $0.00 \%$ & $0.00 \%$ \\
\hline Nicaragua & $1.0 \%$ & $0.7 \%$ & $0.6 \%$ & $1.1 \%$ & & $0.00 \%$ & $0.01 \%$ & $0.00 \%$ & $0.00 \%$ \\
\hline Mexico & $0.4 \%$ & $0.1 \%$ & $0.4 \%$ & $0.2 \%$ & $0.7 \%$ & $0.1 \%$ & & $0.2 \%$ & $0.1 \%$ \\
\hline Brazil & $0.0 \%$ & $0.0 \%$ & $0.0 \%$ & $0.0 \%$ & $0.0 \%$ & $2.4 \%$ & $0.1 \%$ & $0.1 \%$ & $0.1 \%$ \\
\hline USA & $7.1 \%$ & $2.1 \%$ & $9.5 \%$ & $30.1 \%$ & $9.8 \%$ & $0.8 \%$ & $24.1 \%$ & $30.3 \%$ & $1.6 \%$ \\
\hline Germany & $1.2 \%$ & $1.1 \%$ & $0.6 \%$ & $1.9 \%$ & $2.6 \%$ & $0.2 \%$ & $0.3 \%$ & $0.3 \%$ & $3.3 \%$ \\
\hline European Union & $5.3 \%$ & $2.0 \%$ & $1.9 \%$ & $6.0 \%$ & $5.9 \%$ & $1.6 \%$ & $1.0 \%$ & $1.7 \%$ & $13.2 \%$ \\
\hline Memo: & & & & & & & & & \\
\hline Free Trade Zone (USA - Intel) & $13.0 \%$ & $10.1 \%$ & & & & & & & \\
\hline USA reported imports CIF & $19.4 \%$ & $11.8 \%$ & $11.7 \%$ & & & & & & \\
\hline
\end{tabular}

Note: Interpretation of this table is as follows. The table should be read column-wise, where each row represents the share of bilateral exports in the column-countries GDP. As an example, the top-left figure indicates that exports from Costa Rica to El Salvador represent $0.8 \%$ of Costa Rica's GDP. 
Table 7 provides information on the importance of intra-industry trade in Central America based on the adjusted Grubel-Loyed intra-industry trade index. ${ }^{5}$ This index can take values between 0 (no intra-industry trade) to 1 (all trade is intra-industry). There appears to be some importance of intra-industry trade within Central America, however, with the exception of Costa Rica (0.3) there is virtually no evidence of intra-industry trade with the United States. For El Salvador and Guatemala intra-industry trade appears to be quite high with Mexico and Brazil.

Table 7. Intra-industry Trade

\begin{tabular}{|c|c|c|c|c|c|c|c|c|c|}
\hline & Costa Rica & El Salvador & Guatemala & Honduras & Nicaragua & Argentina & Mexico & Canada & France \\
\hline $\begin{array}{l}\text { El Salvador } \\
\text { Guatemala } \\
\text { Honduras } \\
\text { Nicaragua }\end{array}$ & $\begin{array}{l}0.36 \\
0.38 \\
0.40 \\
0.34\end{array}$ & $\begin{array}{l}0.45 \\
0.27 \\
0.15\end{array}$ & $\begin{array}{l}0.33 \\
0.21\end{array}$ & 0.15 & & & & & \\
\hline Mexico & 0.18 & 0.43 & 0.42 & 0.11 & 0.02 & 0.26 & & 0.49 & 0.57 \\
\hline |Brazil & 0.08 & 0.43 & 0.51 & 0.03 & 0.28 & 0.39 & 0.51 & & 0.11 \\
\hline USA & 0.30 & 0.05 & 0.05 & 0.06 & 0.02 & 0.10 & 0.46 & 0.66 & 0.56 \\
\hline Germany & 0.06 & 0.02 & 0.01 & 0.02 & 0.01 & 0.13 & 0.79 & 0.33 & 0.70 \\
\hline
\end{tabular}

\subsection{Business Cycle Synchronization and Trade}

Empirical evidence on trade integration and business cycle synchronization is somewhat mixed. While Frankel and Rose (1998), Choe (2001), Calderon, Chong and Stein (2002) and Calderon (2003) find that a higher trade intensity tends to increase business cycle synchronization, Shin and Wang (2003) find that increasing trade itself does not necessarily lead to more synchronized business cycles, evidence for East Asia suggests that only the expansion of intra-industry trade had such an effect. However, Garnier (2003) find only weak or no relations between intraindustry trade and business cycle synchronization for 16 industrialized countries and conclude that intra-industry trade at most only partially explains business cycle transmission; the low

${ }^{5}$ AIIT $=\frac{\sum_{i}^{n}\left(X_{i}+M_{i}\right)-\sum_{i}^{n}\left|X_{i}-M_{i}\right|}{\sum_{i}^{n}\left(X_{i}+M_{i}\right)-\left|\sum_{i}^{n} X_{i}-\sum_{i}^{n} M_{i}\right|}$, where X and M are exports and imports of industry i

respectively. The adjusted Grubel Llyod index makes an adjustment for trade imbalances. 
correlations reported by Calderon, Chong and Stein (2002) would suggest a similar interpretation for trade intensity and business cycle synchronization.

Using the statistics calculated in the previous section, we attempt to contribute to this debate. Figures 1 shows a cross-plot of bilateral export/GDP ratios and average coherence at business cycle frequency with respect to the United States. ${ }^{67}$ Our findings are in line with more prominent. We are able to identify a positive relationship between trade intensity and business cycle synchronization. We further find that slope of the regression line is quite flat as most countries appear to fall into a relatively narrow range of business cycle synchronization $(0.4$ to 0.5), independent of their level of trade intensity. As an example, despite a big difference in trade intensity, France and Mexico have a similar degree of business cycle synchronization with the United States. ${ }^{8}$ This seems to support Shin and Wang's (2003) and Garnier's (2003) claims that business cycle symmetry is only partly explained by trade intensity. In other words, for El Salvador to reach Mexico's level of BCS with the United States - which is only slightly higher in GDP terms El Salvador would have to more than double its exports to the United States.

\footnotetext{
${ }^{6}$ We find similar results if bilateral exports/ total exports are used as a measure of trade intensity.

${ }^{7}$ Figure A1 in the appendix expands the analysis to all countries covered in Tables 1 and 2.

${ }^{8}$ Argentina's relatively high level of BCS despite low trade intensity appears to be linked to dollarization and capital flow integration.
} 
Figure 1. Business Cycle Synchronization and Trade with the US

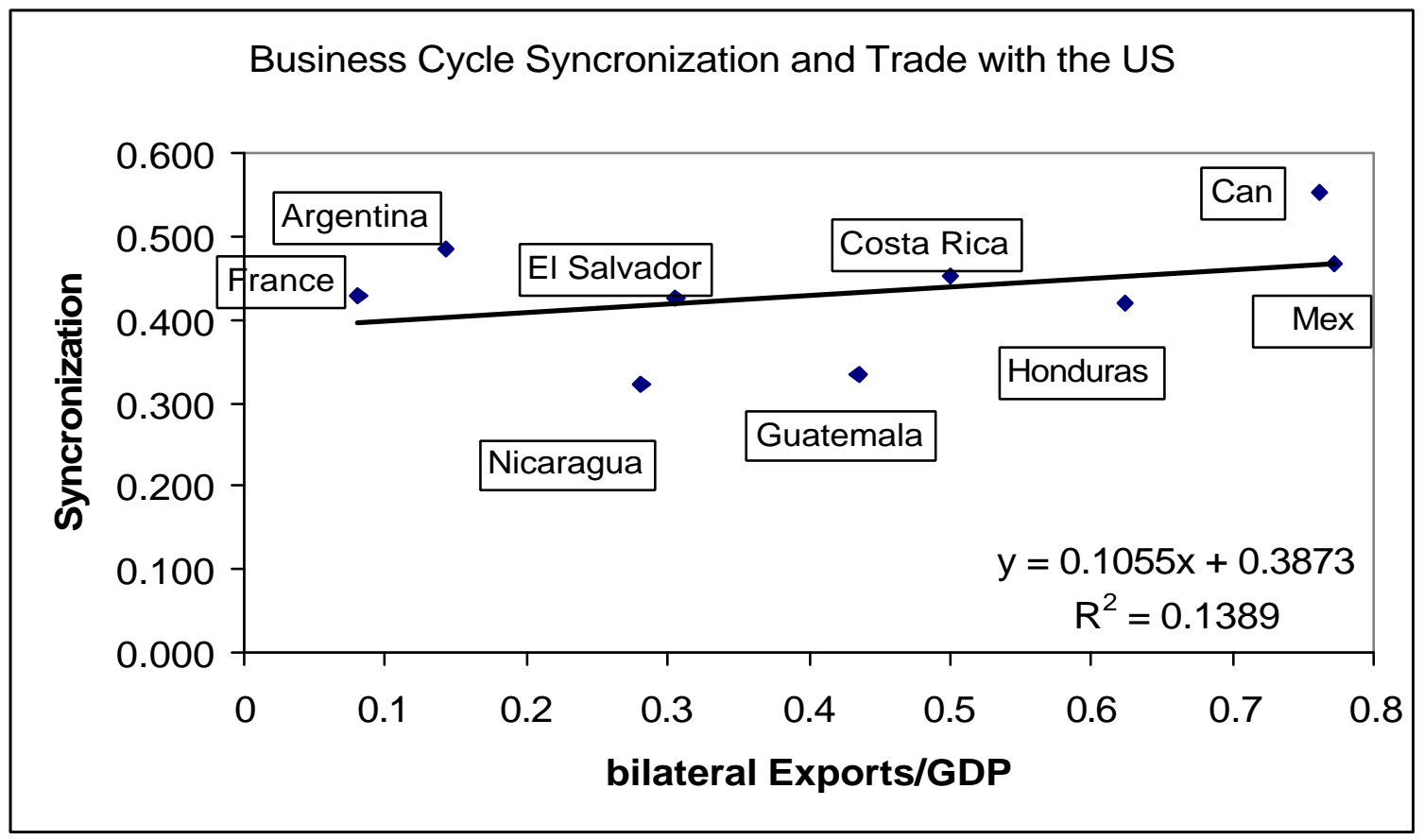

Figure 2. Business Cycle Synchronization and Intra-industry Trade

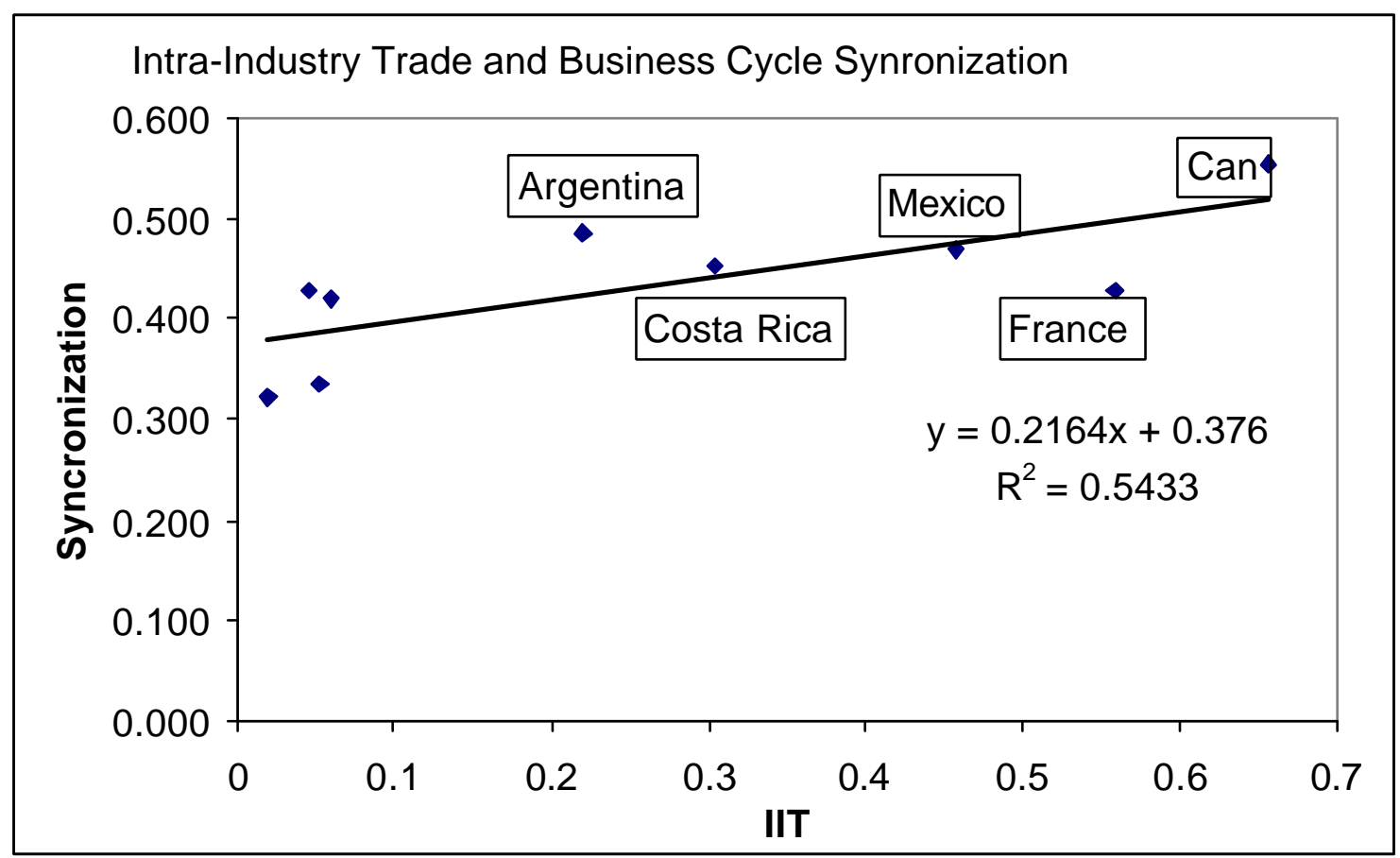

As in Shin and Wang (2003) and Garnier (2003), the link between intra-industry trade and business synchronization is found to be stronger. 


\section{Summary and Concluding Remarks}

- Business cycle synchronization (BCS) within Central America is quite low compared to NAFTA and EU, but not when compared to MERCOSUR.

- BCS in Central America is highest between Costa Rica and El Salvador, El Salvador and Guatemala, El Salvador and Nicaragua and Honduras and Nicaragua.

- Costa Rica and Honduras have a higher degree of BCS with the United States than with any other Central American country. However, BCS with the United States is still below the levels of BCS among NAFTA and even MERCOSUR members.

- Unlike NAFTA, EU and MERCOSUR trade in Central America is not pre-dominantly intra-regional. The United States is by far Central America's most important trading partner.

- With the exception of Costa Rica, there is virtually no evidence of intra-industry trade between Central America and the United States. The level of intra-industry trade within Central America is comparable to that of MERCOSUR, but below the levels of NAFTA (Canada and the United States) and EU (Germany and France).

- The degree of BCS seems only weakly related to trade intensity and trade structure (intraindustry trade), although the relationship between intra-industry trade and BCS is slightly stronger. As such, the gain in BCS through trade expansion seems quite low.

At present neither Central America's trade structure nor its degree of business cycle synchronization appear to make a compelling case for macro coordination within Central America or between Central America and the United States. Central America's trade structure is predominately inter-industry and the current level of business cycle synchronization with the United States is not that high.

Clearly, trade integration is a dynamic process and as trade intensities and compositions of trade flows change so will business cycle patterns. To fully assess the consequences of closer trade integration for the conduct of macroeconomic policies, information about the future evolution of trade structures in CAFTA are needed. If trade becomes more intra-industry (vertical or horizontal), business cycles are expected to become more similar and independence of macro 
policy will be less of a concern. However, if trade integration takes the form of higher interindustry trade then business cycles are likely to diverge fom current levels and the ability to conduct independent macro policies will grow more important.

While information about the future developments of trade patterns within CAFTA is not available, Mexico's experience in NAFTA might provide some indication. Since the signing of NAFTA, there has been a consistent upward trend in IIT between Mexico and the United States. According to Bruehlhart and Thorpe (2001), between 1980 and 1998, the unadjusted GrubelLoyed index (3-digit SITC level) for manufacturing products between the United States and Mexico grew from 0.36 to $0.61 .^{9}$ Mexico's dramatic shift in intra-industry trade with the United States is predominantly explained by increased vertical intra-industry trade in textiles and apparel, and auto industries (Burfisher, Robinson and Thierfelder, 2001). The increase in vertical intra-industry trade has been accompanied with higher business cycle synchronization. Cuveas et al. (2002) claim that macroeconomic synchronization between the United States and Mexico has increased substantially due to NAFTA. Despite this higher level of business cycle synchronization between the United States and Mexico, Cuevas et al. (2002) do however not advocate the adoption of common stabilization policies in NAFTA. For one, despite an increased sensitivity to the United States economy, idiosyncratic shocks continue to be important for Mexico. Second, even though optimal stabilization policies will become qualitatively more important, differences in policy transmission channels would require the ability to apply these policies in different quantities.

\footnotetext{
${ }^{9}$ At the same time, IIT with Canada remained at a relatively constant low level of 0.17.
} 


\section{Appendix:}

Table 8. Business Cycle Synchronization - First Differences - Central America

\begin{tabular}{|lrrrrrr|}
\hline \multicolumn{1}{c}{ Costa Rica } & El Salvardor Guatemala & Honduras & Nicaragua Panama \\
\cline { 2 - 7 } Costa Rica & 1.000 & & & & & \\
El Salvardor & $\mathbf{0 . 6 7 7}$ & 1.000 & & & & \\
Guatemala & $\mathbf{0 . 7 1 3}$ & $\mathbf{0 . 4 9 7}$ & 1.000 & & & \\
Honduras & $\mathbf{0 . 5 0 4}$ & $\mathbf{0 . 3 7 6}$ & $\mathbf{0 . 5 7 5}$ & 1.000 & & \\
Nicaragua & 0.044 & 0.227 & 0.130 & -0.119 & 1.000 & \\
Panama & 0.155 & 0.084 & 0.184 & 0.081 & 0.172 & 1.000 \\
Argentina & $\mathbf{0 . 4 2 8}$ & 0.206 & 0.316 & -0.010 & 0.028 & 0.217 \\
Brazil & 0.014 & 0.013 & -0.145 & -0.099 & -0.116 & -0.024 \\
Mexico & 0.214 & -0.138 & $\mathbf{0 . 5 0 2}$ & 0.306 & -0.096 & $\mathbf{0 . 4 1 6}$ \\
Canada & $\mathbf{0 . 5 7 5}$ & 0.301 & $\mathbf{0 . 4 7 0}$ & $\mathbf{0 . 4 0 3}$ & 0.019 & -0.102 \\
USA & $\mathbf{0 . 5 8 8}$ & $\mathbf{0 . 3 7 5}$ & 0.304 & $\mathbf{0 . 5 6 2}$ & -0.079 & -0.041 \\
France & $\mathbf{0 . 3 7 4}$ & 0.214 & $\mathbf{0 . 5 1 0}$ & 0.250 & 0.064 & 0.143 \\
Germany & 0.241 & 0.180 & $\mathbf{0 . 3 4 1}$ & 0.148 & -0.139 & 0.215 \\
Portugal & 0.286 & 0.062 & $\mathbf{0 . 5 5 2}$ & $\mathbf{0 . 4 2 8}$ & -0.051 & 0.033 \\
Spain & $\mathbf{0 . 4 0 6}$ & $\mathbf{0 . 3 7 7}$ & $\mathbf{0 . 5 0 1}$ & 0.118 & 0.317 & 0.020 \\
UK & 0.303 & $\mathbf{0 . 3 5 6}$ & $\mathbf{0 . 1 0 7}$ & $\mathbf{0 . 3 4 5}$ & -0.195 & -0.269 \\
\hline
\end{tabular}

Table 9. Other FTAs

\begin{tabular}{|c|c|c|c|c|c|c|c|c|c|c|}
\hline & $\begin{array}{l}\text { Merco Sur } \\
\text { Argentina }\end{array}$ & Brazil & $\begin{array}{l}\text { NAFTA } \\
\text { Mexico }\end{array}$ & Canada & USA & $\begin{array}{l}\text { EU } \\
\text { France }\end{array}$ & Germany & Portugal & Spain & UK \\
\hline Costa Rica & 0.428 & 0.014 & $\quad 0.214$ & 0.575 & 0.588 & 0.374 & $\quad 0.241$ & 0.286 & 0.406 & 0.303 \\
\hline El Salvardor & 0.206 & 0.013 & -0.138 & 0.301 & 0.375 & 0.214 & 0.180 & 0.062 & 0.377 & 0.356 \\
\hline Guatemala & 0.316 & -0.145 & 0.502 & 0.470 & 0.304 & 0.510 & 0.341 & 0.552 & 0.501 & 0.107 \\
\hline Honduras & -0.010 & -0.099 & 0.306 & 0.403 & 0.562 & 0.250 & 0.148 & 0.428 & 0.118 & 0.345 \\
\hline Nicaragua & 0.028 & -0.116 & -0.096 & 0.019 & -0.079 & 0.064 & -0.139 & -0.051 & 0.317 & -0.195 \\
\hline Panama & 0.217 & -0.024 & 0.416 & -0.102 & -0.041 & 0.143 & 0.215 & 0.033 & 0.020 & -0.269 \\
\hline $\begin{array}{l}\text { Argentina } \\
\text { Brazil }\end{array}$ & 1.000 & $\begin{array}{l}0.298 \\
1.000\end{array}$ & $\begin{array}{r}0.152 \\
-0.167\end{array}$ & $\begin{array}{l}-0.020 \\
-0.250\end{array}$ & $\begin{array}{l}0.010 \\
0.053\end{array}$ & $\begin{array}{r}0.040 \\
-0.395\end{array}$ & $\begin{array}{l}\mathbf{0 . 3 3 8} \\
0.045\end{array}$ & $\begin{array}{r}0.073 \\
-0.123\end{array}$ & $\begin{array}{r}0.085 \\
-0.295\end{array}$ & $\begin{array}{r}-0.061 \\
0.022\end{array}$ \\
\hline Mexico & & & 1.000 & 0.276 & 0.127 & 0.281 & 0.181 & 0.281 & 0.158 & -0.185 \\
\hline Canada & & & & 1.000 & 0.758 & 0.496 & -0.023 & 0.272 & 0.517 & 0.521 \\
\hline USA & & & & & 1.000 & 0.305 & 0.090 & 0.237 & 0.320 & 0.636 \\
\hline France & & & & & & 1.000 & 0.374 & 0.706 & 0.801 & 0.352 \\
\hline Germany & & & & & & & 1.000 & 0.414 & 0.367 & 0.003 \\
\hline Portugal & & & & & & & & 1.000 & 0.598 & 0.419 \\
\hline Spain & & & & & & & & & 1.000 & 0.366 \\
\hline UK & & & & & & & & & & 1.000 \\
\hline
\end{tabular}


Figure A1. Trade and Business Cycle Synchronization

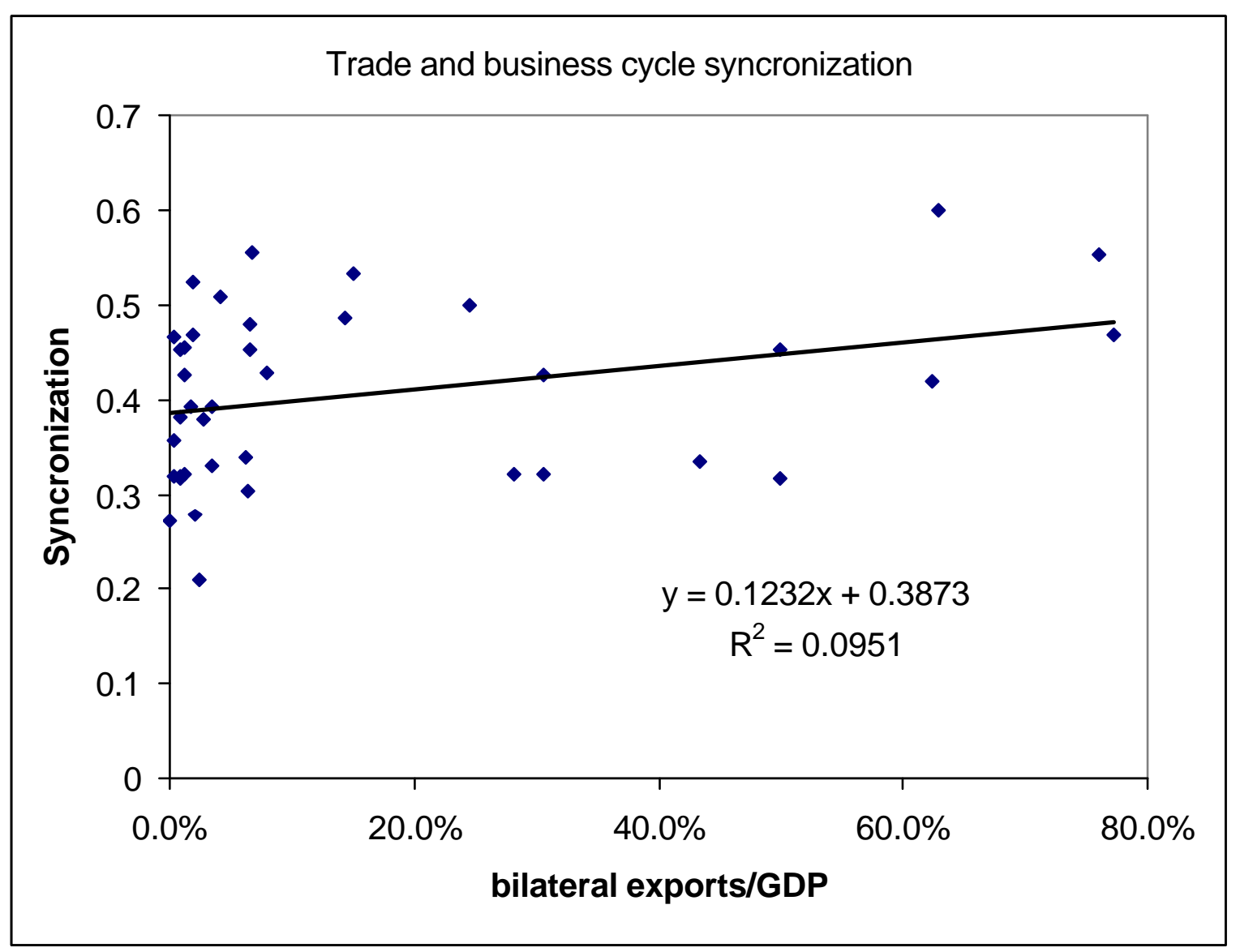




\section{Bibliography:}

Artis, M., and W. Zhang (1995): International Business Cycles and the ERM: Is There a European Business Cycle. Oxford Economic Papers, 51, 120-132.

Bayoumi, T. and B. Eichengreen (1993): Shocking Aspects of European Monetary Unification. in: F. Torres and G. Giavazzi (eds.): Adjustment and Growth in the European Monetary Union, 193-221.

Baxter, M., and R. G. King (1999): Measuring Business Cycles: Approximate Band-Pass Filters for Economic Time Series, Review of Economic and Statistics, 81, 575-593.

Beine, M., and A. Hecq (1997): Asymmetric Shocks inside Future EMU, Journal of Economic Integration, 12, 131-140.

Beine, M., B. Candelon and A. Hecq (2000): Assessing a Perfect European Optimal Currency Area: A Common Cycle Approach, Empirica, 27, 115-132.

Beine, M., B. Candelon and K. Sekkat (1999): Stabilization policy and the business cycle phases in Europe: A Markov switching VAR analysis. SFB 373 Working Paper 91/1999, HumboldtUniversität zu Berlin.

Burfisher, M.E.; Robinson, S.; Thierfielder, K. (2001): The impact of NAFTA on the United States, Journal of Economic Perspectives, 15, 125-144.

Bruehlhart, M.; Thorpe, M. (2001): Export growth of NAFTA members, intra-industry trade and adjustment, Global Business and Economics Review, 3, 1, 94-110.

Calderon, C.; Chong, A.; Stein, E. (2002): Trade intensity and business cycle synchronization: are developing countries any different? Central Bank of Chile Working Papers, No. 195.

Canova F. (1998), Detrending and business cycle facts, Journal of Monetary Economics, 41, 475-512.

Cuevas, A.; Messmacher, M.; Werner, A. (2002): Macroeconomic synchronization between Mexico and its NAFTA partners, World Bank., mimeo.

Filardo, A. J., and S.F. Gordon (1994): International Co- Movements of Business Cycles, Federal Reserve Bank of Kansas, RWP 94-11.

Krolzig, H. M. (2001): Business Cycle Measurement in the Presence of Structural Change: International Evidence,

International Journal of Forecasting, 17, 349-368.

Frankel J.A.; Rose, A.(1998), The endogeneity of the optimum currency area criteria, The Economic Journal, 108,1009-1025. 
Garnier, J. (2003): How much does intra-industry trade matter in business cycle transmission?, mimeo.http://www.iue.it/Personal/Researchers/JulienGarnier/Julien Garnier 3YF II.pdf

Helg, R., P. Manassa, T. Monacelli and R. Rovelli (1995): How Much (A)symmetry in Europe? Evidence from Industrial Sectors, European Economic Review, 39, 1017-1041.

Krolzig, H. M. (2001): Business Cycle Measurement in the Presence of Structural Change: International Evidence, International Journal of Forecasting, 17, 349-368.

Rubin, J., and N. Thygesen (1996): Monetary Union and the Outsiders: A CointegrationCodependence Analysis of Business Cycles in Europe: Economie Appliquée, XLIX (3), 123171.

Breitung, J., and B. Candelon (2001): Is there a European Business Cycle? New Insights from a Frequency Domain Analysis, Vierteljahrshaefte zur Wirtschaftsforschung, 70. Jahrgang, 3/2001, 331-338 